\title{
The Radiation Shielding Properties of the Low Temperature Alloys
}

\author{
Canan AKSOY ${ }^{1}$, , Serdar DizMAN ${ }^{2}$, Bakiye ÇAKIR ${ }^{3}$, Ezgi TAYLAN KOPARAN ${ }^{4}$, Engin TIRAŞOĞLU 5 \\ $1^{*}$ Electronics and Communication Engineering, Faculty of Technology, Karadeniz Technical University, Trabzon, Turkey \\ $2^{2 *}$ Department of Physics, Faculty of Arts and Sciences, Recep Tayyip Erdogan University, Rize, Turkey \\ ${ }^{3}$ Vocational School of Health Services, Artvin Çoruh University, Artvin, Turkey \\ ${ }^{4}$ Department of Mathematics and Science Education, Ereğli Faculty of Education, Zonguldak Bülent Ecevit University, \\ 67300 Zonguldak, Turkey \\ ${ }^{5}$ Department of Physics, Faculty of Science, Karadeniz Technical University, Trabzon, Turkey
}

e-posta: *Corresponding author: cananaksoy@ktu.edu.tr

ORCID ID: http://orcid.org/ 0000-0002-0554-7123 serdar.dizman@erdogan.edu.tr, ORCID ID: http://orcid.org/0000-0002-6511-9526 bcakir@artvin.edu.tr, etaylan20@gmail.com, ORCID ID: $h$ ttp://orcid.org/0000-0003-4339-1913 engint@ktu.edu.tr, ORCID ID: http://orcid.org/0000-0002-4762-2742 ORCID ID: $h$ ttp://orcid.org/0000-0001-7953-5638

Geliş Tarihi: 01.08.2021 Kabul Tarihi: 19.10.2021

\begin{tabular}{|c|c|}
\hline & Ibstrac \\
\hline $\begin{array}{c}\text { Keywords } \\
\text { Attenuation } \\
\text { coefficient; Solder } \\
\text { alloys; WinXCOM; } \\
\text { HpGe detector }\end{array}$ & $\begin{array}{l}\text { Solder alloys are significant for many applications. In addition to the physical electrical and magnetic } \\
\text { properties of solders, it is of great importance to determine the shielding properties of the materials in } \\
\text { order to prevent the harmful effects of radiation on human health if they are used in systems containing } \\
\text { radiation. In this study, the shielding properties of some low temperature solder alloys were } \\
\text { investigated. The alloy samples were tested by the gamma-ray emitted from }{ }^{241} \mathrm{Am} \text { radioactive source } \\
59.5 \mathrm{keV} \text { energy settled into HpGe detector. The highest mass attenuation coefficient and the lowest } \\
\mathrm{HVL} \text { and MFP values were determined for studied samples. The results showed that SDO- } 4 \text { with the } \\
\text { lowest shielding parameters, it is much more suitable for the radiation shielding among the studied } \\
\text { sample. }\end{array}$ \\
\hline
\end{tabular}

\section{Düşük Sıcaklık Alaşımlarının Radyasyon Zırhlama Özellikleri}

\begin{abstract}
Öz
Anahtar kelimeler

Zayıflama katsayısı;

Lehim alaşımları;

WinXCOM; HpGe dedektör

Lehimler birçok uygulama için önemlidir. Lehimlerin fiziksel elektrik ve manyetik özelliklerinin yanı sıra bunların radyasyon içeren sistemlerde kullanılması durumunda radyasyonun insan sağığına zararlarını önlemek açısından malzemelerin zayıflatma özelliklerinin tespit edilmesi büyük önem taşımaktadır. Bu çalışmada, bazı düşük sıcaklık süperiletken lehim alaşımlarının zırhlama özellikleri araştırıldı. Alaşım numuneleri, $\mathrm{HpGe}$ dedektörüne yerleştirilen ${ }^{241} \mathrm{Am}$ radyoaktif kaynaktan $59.5 \mathrm{keV}$ enerjisiyle yayılan gama ışını ile uyarılmıştır. En yüksek kütle soğurma katsayısı ve en düşük HVL, MFP değerleri belirlendi. Sonuçlar, en düşük ekranlama parametrelerine sahip SDO-4'ün, çalışılan örnek arasında radyasyon kalkanı için çok daha uygun olduğunu göstermiştir.
\end{abstract}

(C) Afyon Kocatepe Üniversitesi

\section{Introduction}

New developed superconducting materials are crucial for the electronic and cryogenic applications. The researchers have been investigating novel lead free solders because of the legislation on lead including materials. Tin based solders are good candidate to replace the lead including alloys with their good mechanical properties with high ductility, low melting point. Besides, their electrical and superconducting properties are acceptable for using them in microelectronic and low temperature applications. Among the tin based solders, Snln and SnInBi can be candidates for superconducting applications to replace the currently used lead based solders (Mousavi et al. 2015). The determined binary and ternary solders might be affected from the addition of other superconducting materials such as $\mathrm{MgB}_{2}, \mathrm{YBCO}, \mathrm{Pb}$. These materials have 
already been used for many applications such as ITER and TOKAMAK where the materials exposed to high magnetic field and radiation. Although MgB2 and YBCO have higher melting point comparing the solder formation temperature, their soluble properties might be changed the SnIn solder system. It has already known that lead contribution is effecting the solder and enhancing the superconducting physical, electrics and magnetic properties (Matsumoto et al. 2017). In case of their using in the nuclear research. The shielding properties are quite crucial to determine the thickness to design the radiation absorption level of the used materials for radiation used systems. The attenuation and shielding parameters are the mass and linear attenuation coefficients, and half value layer (HVL), tenth value layer (TVL) and mean free path (MFP). They are evaluated for composite materials [Sürücü and Subaşı 2021], bulk and alloy materials [Şirin 2021, Karadoğan et al. 2021, Aksoy 2021), soils (Sarı and Dizman 2020), minerals [Baltaş et al. 2019], for several pure elements [Kaya et al. 2017]. The Snln alloy used as a based alloy material as $\operatorname{Sn} \ln (35: 65)$ and $S n \operatorname{lnBi}(50: 35: 15)$ were claimed that they have the best superconducting properties among the binary Snln and the ternary $S n \operatorname{lnBi}$ superconducting solders (Mousavi et al. 2015).

The main goal of this study was, determining the shielding properties of the own fabricated alloy solders with contribution of $\mathrm{MgB}_{2}, \mathrm{YBCO}$ to $\mathrm{SnIn}$ and $\mathrm{Pb}$ to $\mathrm{SnInBi}$ solder alloys. The fabricated samples were irradiated by the gamma rays emitted from high-purity germanium detector. The measured mass attenuation coefficients were compared with the theoretical values from the online calculation WinXCOM software.

\section{Materials and Methods}

\subsection{Experimental procedure}

The compositions of the studied samples were given in in table 1 with their label and the density of the each sample. The weighted powders were mixed together for 2 minutes and melted in the alumina crucible at temperatures up to $350{ }^{\circ} \mathrm{C}$ for 1 hour on a hot-plate. The samples were poured in to the $5 \mathrm{~mm}$ radius copper mould and the samples were cut as $1 \mathrm{~mm}$ thickness as seen in Figure 1. The density of the samples were measured by Archimedes method by using pure water.

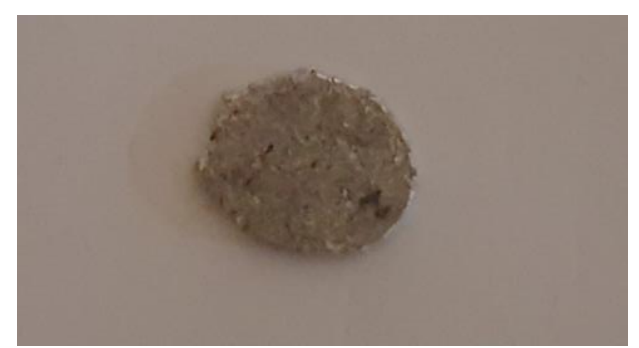

Figure 1. It shows the shape of studied samples

Table 1. The labels and densities of the used samples

\begin{tabular}{lll}
\hline $\begin{array}{l}\text { Chemical } \\
\text { Composition }\end{array}$ & Code & $\begin{array}{l}\text { Density } \\
\left(\mathrm{g} / \mathrm{cm}^{3}\right)\end{array}$ \\
\hline $\mathrm{Sn}_{35} \ln _{65}+2 w t \% \mathrm{YBCO}$ & $\mathrm{SDO}-1$ & 6.20 \\
$\mathrm{Sn}_{35} \ln _{65}+2 w t \% \mathrm{MgB}_{2}$ & $\mathrm{SDO}-2$ & 6.19 \\
$\mathrm{Sn}_{35} \ln _{65}+4 w t \% \mathrm{MgB}_{2}$ & $\mathrm{SDO}-3$ & 6.07 \\
$\mathrm{Sn}_{50} \ln _{35} \mathrm{Bi}_{15}+2 \mathrm{wt} \% \mathrm{~Pb}$ & $\mathrm{SDO}-4$ & 6.14 \\
\hline
\end{tabular}

The produced samples were measured by ORTEC high purity detector emitted gamma ray of using ${ }^{241} \mathrm{Am}$ radioactive source at $59.5 \mathrm{keV}$ energy. The 10 $\mathrm{cm}$ lead shield is used to decrease the background level. The figured experimental set up were illustrated in Figure 2.

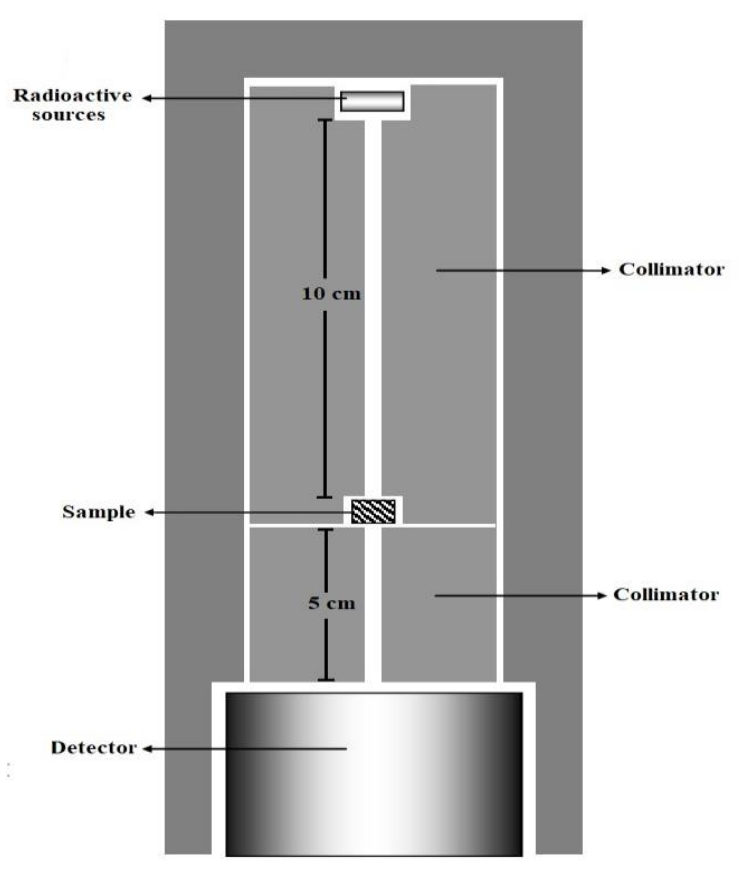

Figure 2. Experimental set-up of the Gamma ray attenuation system. 


\subsection{The calculation of the shielding parameters}

The Beer-Lambert's Law is considered to calculate the shielding parameters are calculated. It was proved that if any material subjects to a gamma-ray, the incident beam is attenuated by $x$ thickness as formulated Equation 1.

$$
I=I_{0} e^{-\mu x}
$$

The mass attenuation coefficients $(\mu / \rho)$ of the samples is calculated by using the mixture rule Eq. (2):

$$
\mu / \rho=\sum_{i} w_{i}(\mu / \rho)_{i}
$$

where $\rho$ is the density of the material, while $w_{i}$ is weight fraction and $(\mu / \rho)_{i}$ is mass attenuation coefficient values of the ith element in the alloy (Scofield 1974, Berger and Hubbell 1987).

Theoretical $\mu / \rho$ of studied solder alloy samples were calculated with WinXCOM online software program (Berger and Hubbell 1987, Gerward et al. 2004).

The Half-Value Layer (HVL) indicates the one-half value of the initial photon which helps the determine the material thickness for shielding, the tenth value layer (TVL) is a tenth of the original intensity and mean free path (MFP) is the material thickness, the average distance a unit of radiation can travel in the material before being absorbed. HVL, TVL, MFP are calculated as following;

$$
\begin{aligned}
& H V L=\ln 2 / \mu \\
& T V L=\ln 10 / \mu \\
& M F P=\frac{\int_{0}^{\infty} t e^{(-\mu t)} \mathrm{dt}}{\int_{0}^{\infty} t e^{(-\mu t)} \mathrm{dt}}=\frac{1}{\mu}
\end{aligned}
$$

\section{Results and Discussion}

The attenuation coefficients were investigated at $59.5 \mathrm{keV}$ emitted gamma ray from ${ }^{241} \mathrm{Am}$ radioactive source. The obtained data from the experiment and the theoretical values of mass attenuation coefficient were calculated by using the normalised sample compositions. The mixture section was used and the energy was added the emitted energy as $59.5 \mathrm{keV}$ in WinXCOM online software programme. The theoretical values were taken from the attenuation without coherent scattering of the total attenuation.

The shielding properties of the investigated samples were also calculated by using linear attenuation coefficient. All data were illustrated in Table 2 and the compared data were given in Fig.3 and Fig.4.

Table 2. The attenuation and shielding data of the studied samples. The relative deviations from the theoretical data were added to the experimental data.

\begin{tabular}{ccccccc}
\hline Sample & $\begin{array}{c}\mu \\
\left(\mathrm{cm}^{-1}\right)\end{array}$ & $\begin{array}{c}\text { TVL } \\
(\mathbf{c m})\end{array}$ & $\begin{array}{c}\text { HVL } \\
(\mathbf{c m})\end{array}$ & $\begin{array}{c}\text { MFP } \\
(\mathbf{c m})\end{array}$ & $\begin{array}{c}(\mu / \rho) \operatorname{Exp} \\
\left(\mathrm{cm}^{2} / \mathrm{g}\right)\end{array}$ & $\begin{array}{c}(\mu / \rho) T h e o \\
\left(\mathrm{~cm}^{2} / \mathrm{g}\right)\end{array}$ \\
\hline SDO-1 & 38.26 & 0.06 & 0.02 & 0.03 & $6.17 \pm 0.02$ & 6.27 \\
\hline SDO-2 & 33.83 & 0.07 & 0.02 & 0.03 & $6.15 \pm 0.01$ & 6.19 \\
\hline SDO-3 & 39.69 & 0.06 & 0.02 & 0.03 & $6.11 \pm 0.01$ & 6.07 \\
\hline SDO-4 & 45.86 & 0.05 & 0.02 & 0.02 & $6.12 \pm 0.01$ & 6.14 \\
\hline
\end{tabular}

The mass attenuation coefficient was given in Fig. 3 with the compared data from the WinXCom. The experimentally obtained data were lower than the theoretical one except the SDO-3 among the other samples. It might be induced from the increased the $\mathrm{MgB}_{2}$ content that reduced the sample density while compared the SDO-2. It may be explained with the photonic interactions such as photoelectric absorption mechanism in low energies (Mariyappan et al.2018). The highest and lowest values were SDO-1 and SDO-3, respectively. It seems that SDO-3 is much more suitable for radiation shielding among the studied samples. 


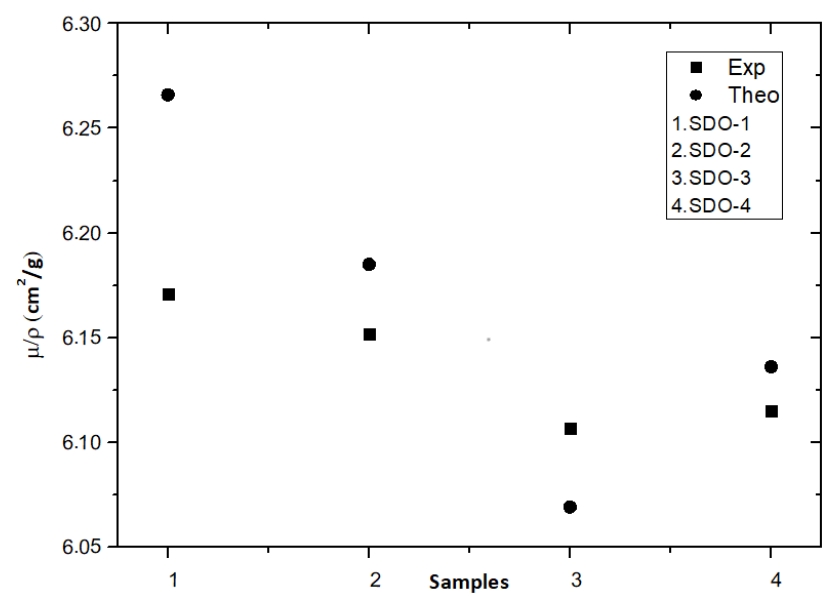

Figure 3. The mass attenuation coefficients at $59.5 \mathrm{keV}$ of the studied alloys

The shielding properties such as HVL, TVL, MFP of the studied materials were plotted in the Fig.4. The compared results showed that the sample has maximum value is SDO-1 and the minimum one is SDO-4.

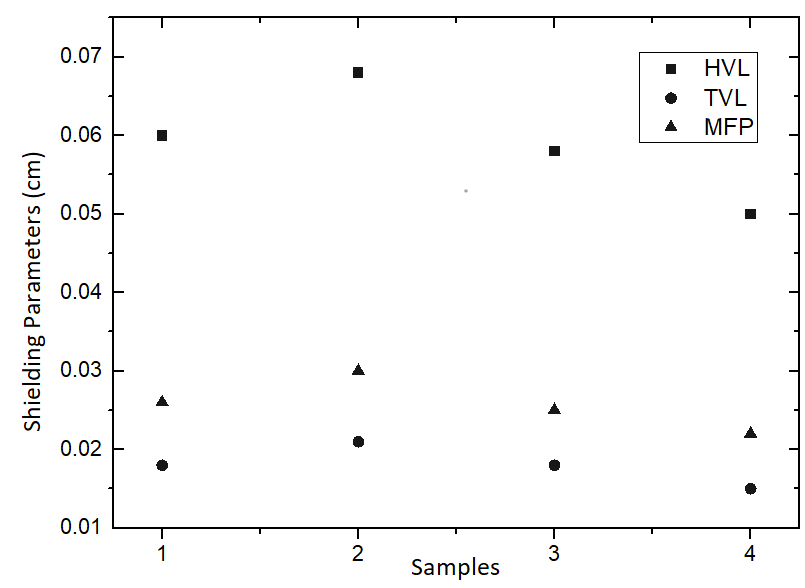

Figure 4. The shielding parameters of the studied samples

Ağar (2018) mentioned that the highest mass attenuation coefficient and the lowest HVL and MFP values are acceptable to determine the best shielding material. Thus, in the current study, it can be said that SDO-4 with the lowest shielding parameters, it is much more suitable for the radiation shielding at $59.5 \mathrm{keV}$. The current results might be useful for the researcher study on the designing of the radiation shield and or various applications.

\section{References}

Ağar, Osman, 2018. "Investigation on gamma radiation shielding behaviour of $\mathrm{CdO}-\mathrm{WO}-\mathrm{TeO} 2$ glasses from 0.015 to $10 \mathrm{MeV}$. Cumhuriyet Science Journal, 39, no. 4: 983-990.

Aksoy, C., 2021. The X-Ray fluorescence parameters and radiation shielding efficiency of silver doped superconducting alloys. Radiation Physics and Chemistry, 186, 109543.

Baltas, H., Sirin, M., Celik, A., Ustabas, \& El-Khayatt, A. M., 2019. Radiation shielding properties of mortars with minerals and ores additives. Cement and Concrete Composites, 97, 268-278.

Berger MJ, Hubbell JH., 1987. XCOM: Photon Cross Sections Database. Web Version 1.2. National Institute of Standards and Technology, Gaithersburg, MD 20899, USA, August 1999 (originally published as NBSIR 87-3597, XCOM: Photon Cross Sections on a Personal Computer, 1987-1999.

Gerward L, Guilbert N, Jensen KB, Leving H.,2004. -a program for calculating X-ray attenuation coefficients. Radiation physics and chemistry. 71: 6534.

Hubbell, J. and Seltzer, S., 1995, Tables of X-Ray Mass Attenuation Coefficients and Mass Energy-Absorption Coefficients $1 \mathrm{keV}$ to $20 \mathrm{MeV}$ for Elements Z = 1 to 92 and 48 Additional Substances of Dosimetric Interest, http://physics.nist.gov/PhysRefData/XrayMassCoef/c over.html (Accessed October 14, 2021).

Karadoğan Işık, Z., Özdemir, Y., Kavaz, E., 2021. Ni Tabanlı Bazı Süperalaşımların Foton Etkileşim Özelliklerinin Incelenmesi, El-Cezeri 8, 552-566.

Kaya, N., Tıraşoğlu, E., Apaydın, G., Aylıkcı, V., \& Cengiz, E. 2007. K-shell absorption jump factors and jump ratios in elements between $\operatorname{Tm}(Z=69)$ and $\mathrm{Os}(Z=76)$ derived from new mass attenuation coefficient measurements. Nuclear Instruments and Methods in Physics Research Section B: Beam Interactions with Materials and Atoms, 262 (1), 16-23.

Mariyappan M., Marimuthu K., Sayyed M.I., Dong M.G., Kara U., 2018. Effect Bi2O3 on the physical, structural and radiation shielding properties of Er3+ ions doped 
bismuth sodium fluoroborate glasses, J. Non-Cryst. Solids, 499, 75-85.

Matsumoto, R., Iwata, H., Yamashita, A., Hara, H., Nishijima, G., Tanaka, M., \& Takano, Y., 2017. Superconducting joints using Bi-added PbSn solders. Applied Physics Express, 10 (9), 093102.

Mousavi. T., Aksoy. C.. Grovenor. C.R.M. \& Speller. S. C.,2015. Microstructure and superconducting properties of $\mathrm{Sn}-\mathrm{In}$ and $\mathrm{Sn}-\mathrm{In}-\mathrm{Bi}$ alloys as $\mathrm{Pb}$-free superconducting solders, Superconductor Science and Technology, 29 (1). 015012.

Sarı S. , Dizman S., 2020. Ovit Dağbaşı Gölü Çevresinden Alınan Toprak Örneklerinde Radyoaktivite ve Radyolojik Etkilerin Araştırılması, 2020, El-Cezeri Cezeri Journal of Science and Engineering , 7, 3, 1122 1130.

Scofield JH., 1974. Exchange corrections of K X-ray emission rates. Physical Review A. 9 (3):1041.

Sirin, M., 2020.The effect of titanium (Ti) additive on radiation shielding efficiency of Al25Zn alloy. Progress in Nuclear Energy, 128, 103470.

Sürücü, A.M and Subaşı S., 2021. "Nanomateryallerin Kompozit Malzemelerin Radyasyon Zırhlama Özelliklerine Etkisinin İncelenmesi." El-Cezeri Journal of Science and Engineering, 8.1: 182-1941. 